\title{
Rate control in atrial fibrillation using Landiolol is safe in critically ill Covid-19 patients
}

\author{
Geoffroy Hariri ${ }^{1,2}$, Tomas Urbina ${ }^{1,2}$, Sandie Mazerand ${ }^{1}$, Naike Bige ${ }^{1}$, Jean-Luc Baudel ${ }^{1}$ and Hafid Ait-Oufella ${ }^{1,2,3^{*}}$ (1)
}

\section{Dear editor,}

Atrial fibrillation (AF) is frequent in shock patients admitted to the intensive care unit (ICU) $[1,2]$ and is associated with increased mortality [1]. Several mechanisms are involved in the development of AF in the context of acute circulatory failure, including hypovolemia and $\beta 1$-adrenergic stimulation in response to endogenous catecholamine production as well as norepinephrine infusion [3]. Atrial fibrillation impairs left ventricular filling and consecutively stroke volume, and in fine potentially aggravates circulatory failure.

Pharmacological options to control AF-related tachycardia are limited. Calcium channel blockers are not frequently used because of long-term negative inotropic effects. Amiodarone is the most used drug but its optimal dosage to fine tune heart rate remains an issue, as well as its potential lung toxicity, especially in case of acute respiratory disease. Landiolol is a beta-blocker with highly $\beta 1$ selective activity, used either in AF patients either to control heart rate or to prevent supraventricular arrhythmia occurrence in the context of cardiac surgery. Landiolol has an ultrashort half-life of $4 \mathrm{~min}$ and weaker negative inotropic effect compared with other intravenous $\beta$-blockers [4]. A recent randomized controlled trial in patient with sepsis/septic shock developing tachyarrhythmia showed that Landiolol infusion efficiently reduced heart rate without any significant hemodynamic side effect [5].

\footnotetext{
*Correspondence: hafid.aitoufella@aphp.fr

${ }^{1}$ Service de réanimation médicale, Assistance Publique - Hôpitaux de Paris (AP-HP), Hôpital Saint-Antoine, 184 Rue du Faubourg Saint-Antoine, 75571 Paris Cedex 12, France

Full list of author information is available at the end of the article
}

Here, we described in critically ill patients admitted to the ICU for SARS-CoV-2 infections presenting with AF, our experience of Landiolol use in terms of efficacy and safety.

\section{Methods}

In our 18-bed intensive care unit, we prospectively collected data from adult patients admitted for SARS-CoV-2 infections with persistent AF. When heart rate was over $120 \mathrm{bpm}$, Landiolol was started at a minimum dose of $0.2 \mu \mathrm{g} / \mathrm{kg} / \mathrm{min}$ and progressively increased by steps of $0.2-0.4 \mu \mathrm{g} / \mathrm{kg} / \mathrm{min}$ every hour to achieve $20 \%$ reduction in heart rate, without bolus. Hemodynamic parameters were recorded every $2 \mathrm{~h}$ during the first $24 \mathrm{~h}$ of drug infusion.

\section{Results}

Fifteen consecutive patients with SARS-CoV-2 infection were treated with Landiolol during a 6-month period. Median age was 70 [67-72] years old, $27 \%$ were female, and median SOFA score was 11 [7-12]. Six patients $(6 / 15,40 \%)$ had a history of chronic AF, and the other had recent AF resistant to electric cardioversion. Median left ventricular (LV) function was 55\% [50-57] (Table 1) and no patient had LV ejection fraction $<40 \%$. All included patients underwent invasive mechanical ventilation support and eleven $(11 / 15,73 \%)$ required norepinephrine. Median time between ICU admission and Landiolol initiation was 2 [0-5] days. Landiolol infusion was started at $0.2 \mu \mathrm{g} / \mathrm{kg} / \mathrm{min}$ and dosage reached $3.9[1.6-7.0] \mu \mathrm{g} / \mathrm{kg} /$ $\min$ at $24 \mathrm{~h}$. Overall heart rate reduction was $23 \%$ (115 [108-117] vs 150 [138-160] bpm; $p<0.01$, Wilcoxon signed-rank test), without any negative impact on global hemodynamic or tissue perfusion parameters (Table 1 ).

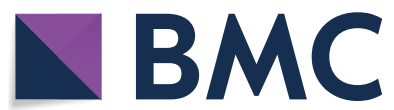

(c) The Author(s) 2021. Open Access This article is licensed under a Creative Commons Attribution 4.0 International License, which permits use, sharing, adaptation, distribution and reproduction in any medium or format, as long as you give appropriate credit to the original author(s) and the source, provide a link to the Creative Commons licence, and indicate if changes were made. The images or other third party material in this article are included in the article's Creative Commons licence, unless indicated otherwise in a credit line to the material. If material is not included in the article's Creative Commons licence and your intended use is not permitted by statutory regulation or exceeds the permitted use, you will need to obtain permission directly from the copyright holder. To view a copy of this licence, visit http://creativecommons.org/licenses/by/4.0/. The Creative Commons Public Domain Dedication waiver (http://creativeco mmons.org/publicdomain/zero/1.0/) applies to the data made available in this article, unless otherwise stated in a credit line to the data. 
Table 1 Global hemodynamic and tissue perfusion parameters before and after (H24) Landiolol initiation

\begin{tabular}{|c|c|c|c|}
\hline \multicolumn{3}{|l|}{ Patient characteristics } & \multirow{2}{*}{$\begin{array}{l}n=15 \\
70[67-72\end{array}$} \\
\hline Age (years old) & & & \\
\hline Women, $n(\%)$ & & & $4(27)$ \\
\hline SOFA & & & $11[7-12]$ \\
\hline Left ventricular ejection fraction (LVE & & & $55[50-57]$ \\
\hline LVEF $\geq 60 \%(n)$ & & & $4 / 15$ \\
\hline LVEF $\geq 50 \%$ and $<60 \%(n)$ & & & $8 / 15$ \\
\hline LVEF $\geq 40 \%$ and $<50 \%(n)$ & & & $3 / 15$ \\
\hline Time between ICU admission and in & & & $2[0-5]$ \\
\hline \multicolumn{4}{|c|}{ Comorbidities, $n(\%)$} \\
\hline Arterial hypertension & & & $8(53)$ \\
\hline Diabetes mellitus & & & $4(27)$ \\
\hline Vascular disease & & & $5(33)$ \\
\hline Norepinephrine, $n(\%)$ & & & $11(73)$ \\
\hline Mechanical ventilation, $n(\%)$ & & & $15(100)$ \\
\hline Hemodynamic kinetics & $\mathrm{HO}$ & $\mathrm{H} 24$ & $p$ \\
\hline \multicolumn{4}{|l|}{ Global hemodynamics } \\
\hline Heart rate (bpm) & $150[138-160]$ & 115 [108-117] & $<0.01$ \\
\hline Systolic blood pressure (mmHg) & 115 [99-130] & $120[108-125]$ & 0.70 \\
\hline Diastolic blood pressure $(\mathrm{mmHg})$ & $58[51-74]$ & $60[53-66]$ & 0.71 \\
\hline Mean arterial pressure (mmHg) & 79 [69-89] & $76[72-88]$ & 0.76 \\
\hline Norepinephrine dose $(\mu \mathrm{g} / \mathrm{kg} / \mathrm{min})$ & $1[0.4-1.5]$ & $0.7[0.2-1]$ & 0.04 \\
\hline \multicolumn{4}{|l|}{ Tissue perfusion parameters } \\
\hline Index capillary refill time (s) & $2[1.5-2.5]$ & $2[1.6-2.5]$ & 0.75 \\
\hline Mottling score $n(\%)$ & & & 0.62 \\
\hline $0-1$ & $12(80)$ & $13(87)$ & \\
\hline $2-3$ & $1(7)$ & $2(13)$ & \\
\hline$>4$ & $2(13)$ & $0(0)$ & \\
\hline Arterial lactate level (mmol/L) & $3.2[2-4.9]$ & $2.2[1.7-2.8]$ & 0.05 \\
\hline
\end{tabular}

Interestingly, during Landiolol infusion, norepinephrine need decreased in $9 / 11$ patients $(81 \%)$, and mean norepinephrine dose significantly decreased $(0.7[0.2-1]$ vs 1 [0.4-1.5] $\mu \mathrm{g} / \mathrm{kg} / \mathrm{min} ; p=0.04$, Wilcoxon signed-rank test) (Fig. 1).

\section{Discussion}

In this observational uncontrolled study, Landiolol was safely used to lower heart rate in critically ill patients with AF with normal or moderately altered cardiac function. Given that most patients under mechanical ventilation for SARS-CoV-2 infections received norepinephrine and that some of them had moderate left ventricular systolic function, Landiolol infusion was started at very low doses and maximal infusion rate at $24 \mathrm{~h}$ was lower than reported in studies on non-critically ill patients [6]. Using this protocol, hemodynamic tolerance was excellent without any significant arterial hypotension or alteration in peripheral tissue perfusion. Moreover, we observed a decrease in norepinephrine need after Landiolol initiation. Additional studies are required to investigate the potential beneficial mechanisms of Landiolol on global hemodynamics.

Acknowledgements

Not applicable.

Authors' contribution

Study concept and design, all authors. Acquisitions of data, G.H., T.U. and H.A.O. Drafting of the manuscript, G.H., T.U., H.A.O.. Critical revision of manuscript, all authors. Statistical analysis, G.H. and H.A.O. All authors read and approved the final manuscript.

Funding

None.

Availability of data and materialS

The datasets used and/or analyzed during the current study are available from the corresponding author on reasonable request.

Ethics approval and consent to participate

Not applicable for monocenter observational study. 


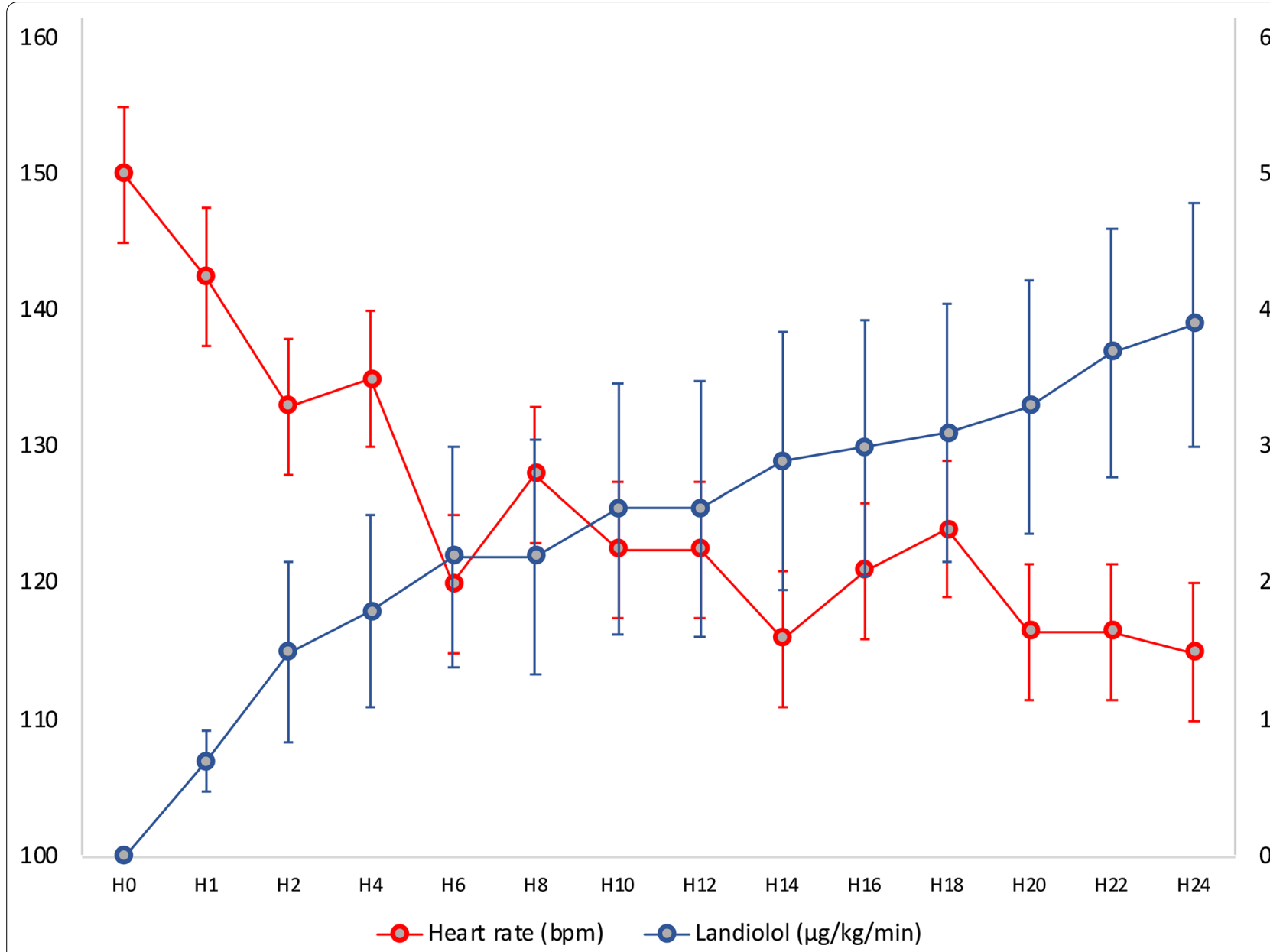

Fig. 1 Heart rate (Red) and Landiolol dosage (blue) changes during the first $24 \mathrm{~h}$ of Landiolol infusion

\section{Consent for publication}

Not applicable.

\section{Competing interests}

The authors declare that they have no competing interests. H.A.O. declares having received fees for medical trainings from the laboratories AMOMED.

\section{Author details}

1 Service de réanimation médicale, Assistance Publique - Hôpitaux de Paris (AP-HP), Hôpital Saint-Antoine, 184 Rue du Faubourg Saint-Antoine, 75571 Paris Cedex 12, France. ${ }^{2}$ Sorbonne Université, Paris, France. ${ }^{3}$ Inserm U970, Centre de Recherche Cardiovasculaire de Paris (PARCC), Paris, France.

Received: 28 December 2020 Accepted: 13 January 2021

Published online: 22 January 2021

\section{References}

1. Steinberg I, Brogi E, Pratali L, Trunfio D, Giuliano G, Bignami E, Forfori F. Atrial fibrillation in patients with septic shock: a one-year observational pilot study. Turk J Anaesthesiol Reanim. 2019;47(3):213-9.

2. Meierhenrich R, Steinhilber E, Eggermann C, Weiss M, Voglic S, Bogelein D, Gauss A, et al. Incidence and prognostic impact of new-onset atria 